\title{
Research
}

\section{Connecting Social Networks with Ecosystem Services for Watershed Governance: a Social-Ecological Network Perspective Highlights the Critical Role of Bridging Organizations}

\author{
$\underline{\text { Kaitlyn J. Rathwell }}^{1,2}$ and Garry D. Peterson ${ }^{2}$
}

\begin{abstract}
In many densely settled agricultural watersheds, water quality is a point of conflict between amenity and agricultural activities because of the varied demands and impacts on shared water resources. Successful governance of these watersheds requires coordination among different activities. Recent research has highlighted the role that social networks between management entities can play to facilitate cross-scale interaction in watershed governance. For example, bridging organizations can be positioned in social networks to bridge local initiatives done by single municipalities across whole watersheds. To better understand the role of social networks in social-ecological system dynamics, we combine a social network analysis of the water quality management networks held by local governments with a social-ecological analysis of variation in water management and ecosystem services across the Montérégie, an agricultural landscape near Montréal, Québec, Canada. We analyze municipal water management networks by using one-mode networks to represent direct collaboration between municipalities, and twomode networks to capture how bridging organizations indirectly connect municipalities. We find that municipalities do not collaborate directly with one another but instead are connected via bridging organizations that span the water quality management network. We also discovered that more connected municipalities engaged in more water management activities. However, bridging organizations preferentially connected with municipalities that used more tourism related ecosystem services rather than those that used more agricultural ecosystem services. Many agricultural municipalities were relatively isolated, despite being the main producers of water quality problems. In combination, these findings suggest that further strengthening the water management network in the Montérégie will contribute to improving water quality in the region. However, such strengthening requires developing a network that better connects both agricultural and tourism oriented municipalities. Furthermore, these findings show that consideration of the social-ecological context of social networks, can help explain the structure of networks and reveal social-ecological clusters and disconnects in a network.
\end{abstract}

Key Words: agricultural watershed, agriculture, bridging organization, ecosystem services, Montérégie, Richelieu River Québec, social-ecological feedback, social-ecological system, social network analysis, social networks, tourism, two-mode network, water quality, watershed, watershed management, Yamaska River Québec

\section{INTRODUCTION}

Water has been called the bloodstream of the biosphere because of the way it connects distant places (Ripl 2003). In our human dominated world, water also connects people who live in different places, and these connections bring opportunities and conflicts. In many densely settled agricultural watersheds, water quality is a point of conflict between amenity, e.g., tourism related, and agricultural activities. This is because excess fertilizer from agriculture pollutes water, in turn reducing water quality and impairing the production of drinking water, swimming, and fishing (Carpenter et al. 1998). Additionally, lowered water quality can cause substantial economic losses if it reduces tourism or triggers declines in the value of waterfront property (Leggett and Bockstael 2000). Successful governance of agricultural watersheds requires coordination of activities between agricultural and amenity-based water user groups to produce mutually desired outcomes. In practice, however, coordination is difficult because of differences in practices, interests, values, and management structures among these groups (Lubell et al. 2002, Ison et al. 2007, Lubell and Fulton 2008).

To improve coordination in agricultural watersheds, governments and nongovernmental organizations have invested in building networks among users and userorganizations. Network building investments have often created or funded bridging organizations to support and maintain collaborative networks (Imperial 2005, Lubell and Fulton 2008, Pahl-Wostl and Kranz 2010). Bridging organizations are organizations whose activities mediate connection between people or groups who would otherwise have not been connected (Berkes 2007). In a mediating position, bridging organizations can facilitate coordinated and consistent management action between actors/actor groups who lack resources, mandates, or interest in connecting directly with each other. Cross-scale linkages, horizontally across landscapes and vertically between actors from local to watershed scale, are especially important for shared resources, such as water, whose users operate at multiple spatial scales

${ }^{1}$ University of Waterloo, Waterloo, Canada, ${ }^{2}$ Stockholm Resilience Centre, Stockholm University, Sweden 
(Cash et al. 2006, Olsson et al. 2007). Social network analysis has been used to understand how bridging organizations enable coordination among actors (Olsson et al. 2007), however, research is just beginning to explore how bridging organizations contribute to the structure and functioning of networks for robust natural resource management (Marín and Berkes 2010).

We used one-mode networks to represent direct collaboration between municipal units, and two-mode networks to capture how bridging organizations indirectly connect municipalities (Scott 2000). Scholars in both the social and natural sciences have utilized social network analysis (SNA) as a tool to analyze interactions among individuals and groups (see Borgatti et al. 2009 for a summary). In social networks, nodes represent people or organizations, whereas links represent relations between nodes, such as communication patterns, collaborations, or resource exchange (Bodin and Crona 2009). Once a system has been defined in terms of nodes and links, the network can be analyzed using SNA (Wasserman and Faust 1994, Scott 2000). Social network structure can be used to analyze how patterns of linkage vary among nodes, and how variation in connectedness influences the behavior of network nodes.

We used social network analysis to examine how local governments, in our case municipalities, work with one another directly, and indirectly via bridging organizations to manage water across an agricultural landscape. The study of social-ecological systems has benefitted from using social network analysis techniques developed in fields such as sociology, organizational science, and public administration (Provan and Kenis 2008, Scholz et al. 2008, Bodin and Crona 2009, Pahl-Wostl and Kranz 2010) to examine how social network structure affects network performance and activity (Sandström and Carlsson 2008, Newig et al. 2010). We build upon this work by examining how social-ecological context is related to network structure and activity. By combining social network analysis with geographical information systems (GIS) and spatial analysis, we mapped and assessed how collaborative water quality management networks are shaped by heterogeneity within a social-ecological landscape.

We did this for a portion of the Monterégie region, an agricultural landscape near Montréal, Canada. We assessed the municipal ecosystem service use (Raudsepp-Hearne et al. 2010) to identify the social-ecological orientation of each municipality toward agriculture or tourism related ecosystem services. We collected information on how municipalities manage water by assessing to what extent they engage in municipal water management activities and how they collaborate with each other and bridging organizations in social networks to manage water (Fig. 1). We quantitatively investigated the relationships between the social network attributes of municipalities and municipal engagement in water quality management. Our research made explicit connections between social network structures and the ecological landscape these networks manage by answering three inter-related questions:

1. How are municipalities collaborating to address water quality management?

a) with each other (in one-mode networks)

b) with other governmental and nongovernmental and bridging organizations (in two-mode networks)

2. Are the activities and networks of tourist and agricultural municipalities different?

3. Do more connected municipalities engage in more water quality management activities?

Fig. 1. Our research analyzes a social-ecological landscape by examining how direct (black) and indirect (purple) social networks among municipalities are related to municipal water management activities, and the agricultural or tourism oriented use of ecosystem services within each municipality.

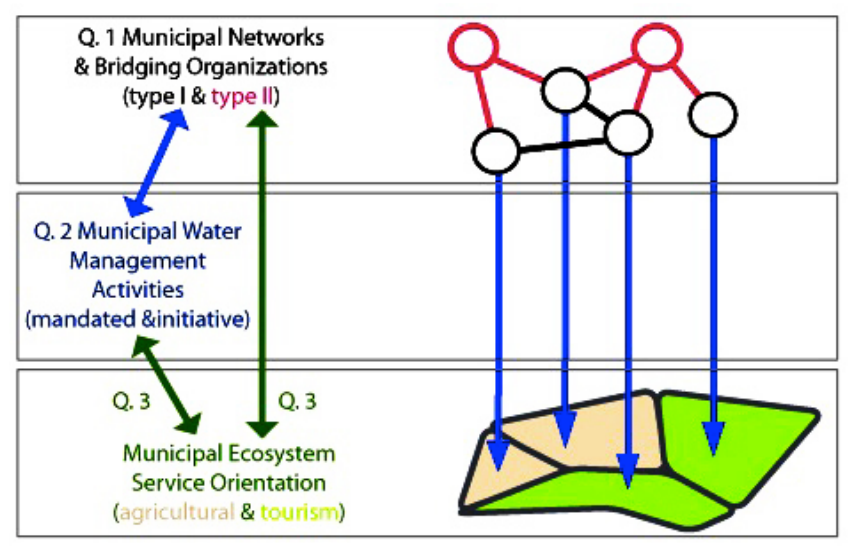

These questions allowed us to understand how the region's social networks shape, and in turn are shaped by, the socialecological landscape within which they are embedded. The question of how municipalities collaborate with one another is important because coordination is required to ensure that a municipality's efforts to improve water quality are not offset by continued pollution from other watershed users. Because poor water quality is a problem in the Montérégie and management of water quality a legally mandated task in the region, we expected that municipalities would work with one another to address these problems (Government of Québec 2002, Mimeault 2002). Furthermore, there are governmental and nongovernmental organizations in the area that have been established to work with and connect municipalities within the region, regarding general issues of governance and to 
specifically address water quality issues. We expected that these organizations would facilitate connections among the municipalities.

Assessing differences between tourism and agriculturally oriented municipalities is important because agriculture and amenity-based uses of ecosystems encourage activities whose respective use of water conflict with each other. Because social networks often exhibit homophily, meaning that similar actors connect to one another (Schneider et al. 2003, Newman and Dale 2007), it is expected that municipalities with similar problems would be more likely to work together than those whose problems differ (Coleman 1990, Lin 2001). However, solving water quality problems requires collaboration between agriculturally and tourism oriented municipalities, because most of the water quality problems originate from agricultural activities (Delisle et al. 1998, Mimeault 2002, Gangbazo and Babin 2000). We expected that neighboring municipalities should be more likely to work on projects together than nonneighboring municipalities, because neighbors are more likely to have shared problems, such as a eutrophic lake that crosses municipal boundaries. Working together to address these problems can be expected to be cheaper and more successful than working alone. To test if patterns of collaboration vary among municipalities with different ecosystem service orientations, we compared how direct or indirect collaborations among municipalities are related to a municipality's utilization of agriculture or tourism related ecosystem services, or whether it is a neighbor of its collaborators.

Assessing whether municipalities with more connections in social networks engage in more water quality management activities is important because social network theory suggests municipalities that have more connections to others should have more capacity to engage in activities (Schneider et al. 2003, Scholz et al. 2008). However, there is not a broad body of empirical work to support this belief, especially in the context of common pool resources, such as shared freshwater resources (Bodin and Crona 2009). It is expected that more connected municipalities are more likely to be engaged in water management activities than less connected municipalities. Such a relationship between collaboration and activities would suggest that investments in building networks between resource users are sensible, whereas a negative relationship would suggest they are not.

\section{METHODS}

\section{Study site}

Our research examined 34 municipalities located on a transect across the Montérégie of Québec, Canada (Fig. 2). The Montérégie is east of metropolitan Montréal, Québec, Canada, and a city of 3.6 million people. The Montérégie itself is inhabited by about 1.4 million people and includes the
Richelieu and Yamaska watersheds whose Canadian portions cover an area of about $7300 \mathrm{~km}^{2}$ (Raudsepp-Hearne et al. 2010). In Québec, municipalities are spatially defined administrative governing units. Each municipality plays an important role in local water quality management and is responsible for the implementation of government rules and regulations, such as buffer zones around rivers and streams.

Fig. 2. Our Montérégie study region is in Québec, just north of Canada's border with the USA. It includes 34 municipalities from the Richlieu and Yamaska watersheds. Municipalities are divided into two groups based on a cluster analysis of six ecosystem services. Municipalities oriented toward agricultural production are shaded pink and tourism oriented municipalities are shaded green.

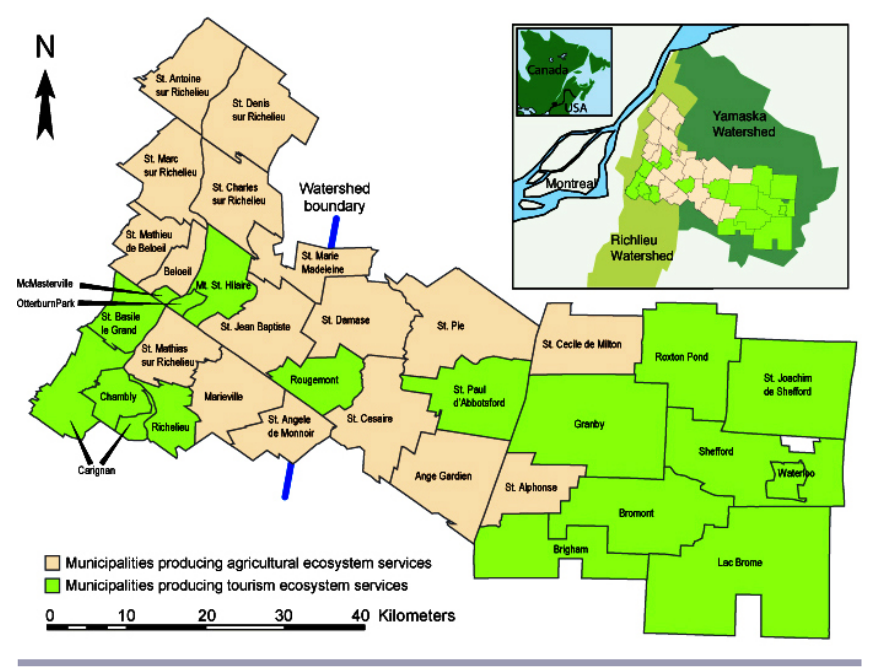

The Montérégie has a substantial water quality problem that has resulted in lake closures and significantly impacted the tourism industry. Water quality in several rivers is below regulatory standards, and provincial and local governments are required to address these problems. The transect of municipalities was chosen to span the diversity of ecosystems across the region to facilitate an analysis of how municipalities with different ecosystem services interact in social networks to manage water quality. Within Québec, the Montérégie is known for its orchards, food, and mountains, but the region combines suburbs, intensive agriculture, tourism, and regional towns. In the west, near Montréal, agricultural land is being converted to housing, while apple orchards and regional forests attract tourists. In the center of the region, industrialized farming and large-scale pork production dominate the landscape. In the east, the landscape is forested and contains many summer cottages (Raudsepp-Hearne et al. 2010). Large rivers, streams, and lakes connect the municipalities. For example, the Yamaska River flows between municipalities with dense forested hills and municipalities with industrial agriculture. 
Our study region contains municipalities that fall within two large watersheds, the Yamaska and Richelieu. Direct collaboration between municipalities in different watersheds will not have the same direct impact on water quality as collaborations within the same watershed. However, regional collaborative networks are important because some municipalities are in both watersheds and collaboration between watersheds can enhance knowledge sharing and improve water management practices.

\section{Social networks}

We collected data on social network ties and management activities performed by municipalities using structured interviews with representatives from each of the 34 municipalities in the study site (Appendix 1). We used this data to construct networks that show direct connections among municipalities (one-mode network) and indirect connections via bridging organizations (two-mode network).

In each municipality, mayors or directors general were asked to identify the actor groups their municipality collaborates with for water quality management. These representatives were chosen because they oversee all projects and activities involved at the municipal level. They are also the representatives for their municipalities on boards and committees, giving them a good understanding of how their municipality interacts with other organizations. Interviewees were asked to relate (a) which other municipalities they collaborate with for management of water resources, and (b) which bridging organizations, formal government agencies, and NGOs their respective municipality collaborates with regarding water quality management. They were first allowed to give an open-ended answer before being asked to choose from a list of government and nongovernmental organizations. This list was developed in preliminary interviews and previous regional analyses (Appendix 2). After initial analysis of the network data, a second round of interviews was performed to clarify nonreciprocated ties between municipalities. Only reciprocated ties between municipalities are used in our analysis.

This analysis investigates only collaborative ties. Collaborative network ties are the strongest of four types of interaction investigated in our research study and were defined during interviews as situations in which municipalities collaborate to "organize joint projects and activities" (see Appendix 1). In this context collaboration implies a shared vision and meaningful interaction to execute joint projects and activities. Our analysis focuses on collaborative ties because they are the strongest ties in the landscape and result in changes in ecological management.

We analyzed connections among municipalities using oneand two-mode networks (Scott 2000). One-mode networks were used to analyze the direct connections among municipalities, and two-mode networks were used to analyze the networks among municipalities that are formed indirectly via their collaborations with bridging organizations. The networks were analyzed and graphed using the SNA package (Butts 2005) in the statistical software R (R Development Core Team 2010). We used Arc Map GIS and R to display how collaborations among municipalities and organizations are spatially distributed across the study region.

To determine the one-mode network of collaboration between municipalities we created socio-matrices representing collaborative ties between municipalities $(n=34$; Wasserman and Faust 1994). Because other governmental and nongovernmental organizations also work with municipalities and influence water quality management, we analyzed how municipalities were indirectly connected to each other via these organizations by creating a two-mode network. Municipal representatives were asked to create a list of the organizations they collaborated with for water quality management $(n=64)$. If municipalities collaborated with the same organization, they were considered indirectly connected (two-mode network). We considered organizations that indirectly connect multiple municipalities to bridging organizations and the connectivity of these bridging organizations was ranked based on the number of collaborative ties they have with municipalities.

\section{Social-ecological heterogeneity: agriculture vs. tourism}

We categorized each municipality as agriculture or tourism oriented based on its use of ecosystem services. We made this distinction using a K-means cluster analysis in the statistical program $\mathrm{R}$ to separate municipalities into two groups based on data for six ecosystem services; crop production (\% municipal land used for crop production), pork production (number of pigs produced per $\mathrm{km}^{2}$ ), forest recreation (\% of municipal land covered by forest), nature appreciation (number of reported sightings of rare species per $\mathrm{km}^{2}$ ), summer cottages (tax value of cottages per $\mathrm{km}^{2}$ ), and tourist attractions (number of tourist attractions per $\mathrm{km}^{2}$; Raudsepp-Hearne et al. 2010). By separating municipalities into these groups, we accounted for $67 \%$ of the variation among municipalities in these ecosystem services. As can be observed in Figure 2, the agricultural and tourist municipalities are spatially clustered (Moran's I, P < 0.01).

We used t-tests to compare tourist and agricultural municipalities as groups, to determine if they have different numbers of overall collaborations or engage in different amounts of water quality management activity. We also used t-tests to determine if the connections of bridging organizations, divided into government agencies and nongovernmental organizations tended toward tourist or agricultural municipalities. As well, t-tests revealed whether tourist and agricultural municipalities were more likely to connect to other municipalities of their type. We tested for 
spatial auto-correlation of bridging organization links using Moran's I.

\section{Water quality management activities}

Interviewees were asked about the actions their municipality employed regarding water quality management. They were then asked if their municipality employed specific water quality management activities, from a list of 30 activities (Appendix 2). If management activities were implemented, interviewees were also asked if any other organizations were involved in the implementation. The list of activities consists of government rules and regulations, projects, and activities described by municipalities or outlined on the web pages of nongovernmental organizations operating in the region. Governmental obligations for water quality management were found in government documents and from preliminary interviews with representatives of MRCs, i.e., regional government organizations whose French name can be translated as Municipal Regional Counties. These organizations belong to an administrative level that oversees municipalities. Each MRC is composed of several municipalities. Activities were organized in a database and categorized based on our own criteria of activity type.

We classified the activities into four categories to separate activities based on collaboration from activities a municipality undertook alone. We also separated legally mandated activities from those undertaken on the initiative of a municipality. Total activities define all management activities pursued by a municipality. Initiative-based activities, such as management plans for protected areas and lake experiments, describe activities a municipality pursues beyond the implementation of government rules and regulations. Total activities alone, and total initiative-based activities alone are subsets of the above categories defined to distinguish between activities municipalities report doing alone and activities that municipalities report doing with the support/leadership/ collaboration of another municipality, organization, or government agency.

\section{Networks and water quality management activities}

We tested whether the number of collaborative ties a municipality had was related to engagement in water quality management activities. We did this by testing whether the number of collaborative ties was correlated with (a) the total number of water quality management activities municipalities performed alone, (b) the number of initiative-based, i.e., not required by regulation, activities municipalities performed alone, and (c) the total number of water management activities performed. We use the subset of total activities alone to control for the likely confounding influence of collaborative activities with number of collaborations, and total initiative-based activities alone to test whether the number of collaborations in social networks is related to the number of activities that are not required by regulation.
To control for the impact of other aspects of land-use, demography, and world-view that vary among municipalities, we used hierarchical portioning. Hierarchical portioning is a statistical method that analyzes all possible models in a multiple regression to identify the contribution of each variable to the total variance, both independently and in conjunction with the other variables, to infer the impact of each variable (Chevan and Sutherland 1991, MacNally 2002). Specifically, we used hierarchical portioning to test the independent effect of collaboration in conjunction with the proportion of the municipality in cropland, average income, population density, the presence of an environmental committee council, and whether municipalities considered "water quality to be an important problem" or "regional algae to be an important problem." We applied the hierarchical portioning approach using the 'hier.part' package (MacNally and Walsh 2004) in R (R Development Core Team 2010). We assumed Gaussian errors and calculated goodness of fit using $\mathrm{R}^{2}$. The statistical significance of the independent effect of each variable was determined using a randomization approach $(\mathrm{n}=1000)$ to calculate $\mathrm{Z}$ scores (MacNally 2002).

\section{RESULTS}

\section{Social networks}

There was a low level of connectivity between municipalities (Fig. 3). The one-mode analysis of municipal collaboration revealed only two examples of collaborative network ties between municipalities for shared water management activities in the region, and both were between neighbors (Fig. $3 a)$. The two-mode network revealed that indirect connections via bridging organizations are much more common than direct connections between municipalities (Fig. 3b,c,d). Although there were only two links between municipalities, municipalities have 55 links with NGOs and 51 links with government organizations.

Municipalities exhibited a wide range of collaborative behavior. The range included municipalities that were not connected to others, through to municipalities that were connected to several bridging organizations in addition to other municipalities (Fig. 4). A few municipalities, such as Saint-Alphonse and Saint-Damase, had no collaboration regarding water quality with other municipalities or bridging organizations. Disconnected municipalities were, for the most part, situated in the center of our study region. Most municipalities maintained no collaboration with other municipalities but were connected to the larger water quality management network via bridging organizations. Figures 3 and 4 show that although most municipalities did not collaborate with each other, many collaborated with governmental and nongovernmental organizations. Finally, a small group of municipalities, such as Shefford and Waterloo, had both local collaborations for water quality management with neighboring municipalities as well as robust collaborative 
Fig. 3. The social networks among municipalities for water quality management. The size of the red circle in each municipality corresponds the number of municipal links. Unlinked municipalities are shaded grey. a) Direct collaborations among municipalities (one-mode). b) Municipal collaborations with government agencies (two mode). c) Municipal collaborations with NGOs. d) All collaborations (one and two mode). Municipalities oriented toward agricultural production are shaded pink, while tourism oriented municipalities are shaded green.

3a)

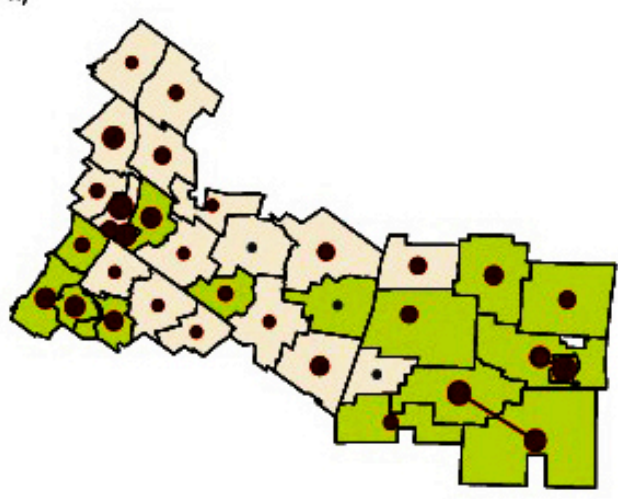

3c)

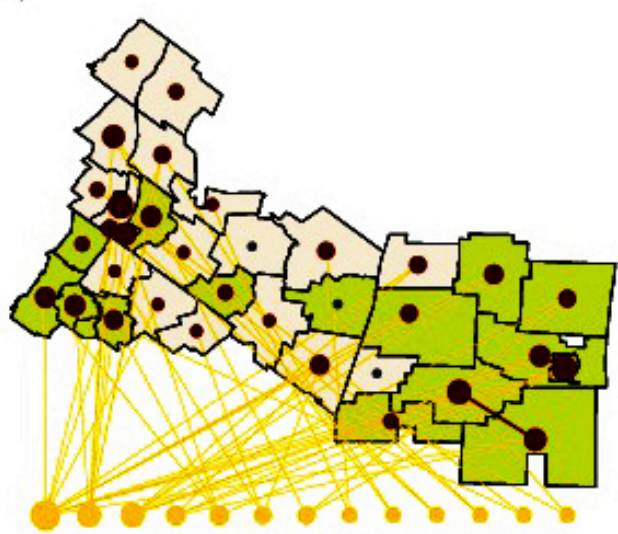

3b)

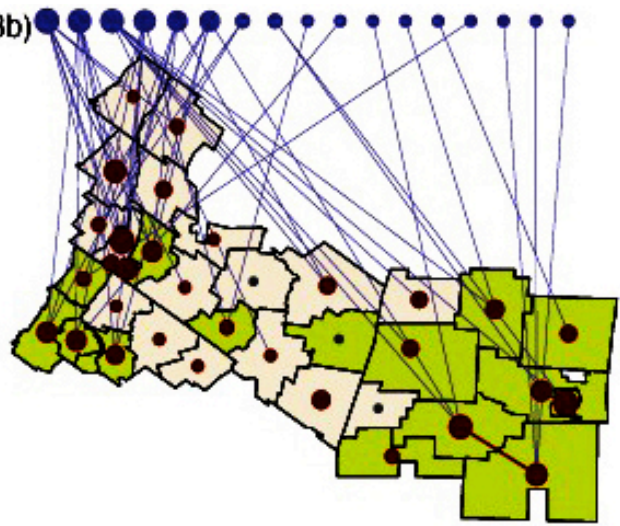

3d)

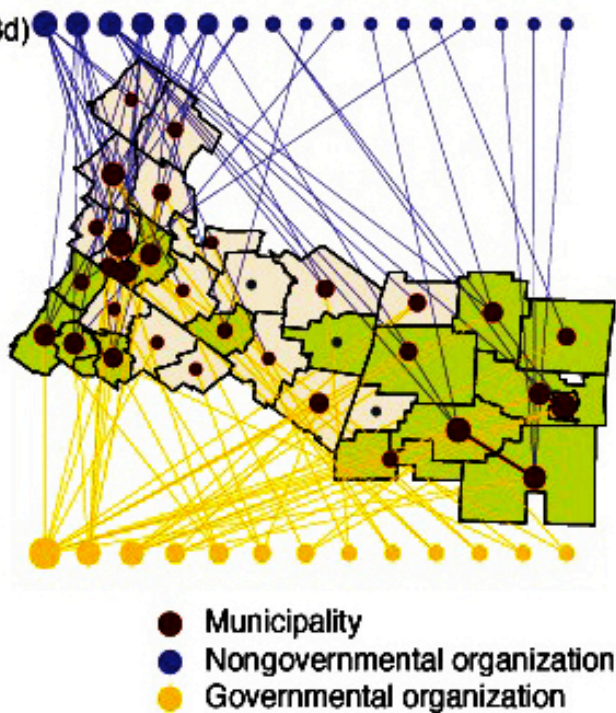

network ties with government and nongovernmental bridging organizations. The activity of bridging organizations was spatially clustered $(P=0.013)$, but there were no significant differences in network structure between the two watersheds under investigation. Consequently, some areas of the landscape had a high concentration of collaboration with these bridging organizations, whereas others had few (Fig. 5). For example, in the east the municipality of Beloeil was connected to three organizations and five government agencies, whereas Saint-Alphonse, Saint-Damase, and Sainte-Paul d'Abbotsford, in the center of the study region, were not connected to any organizations or municipalities. In summary, the water quality management network was dense for a few municipalities, sparse for many more, and absent for a few others.

Twenty bridging organizations connected municipalities to each other in the Monterégie. However, the seven most connected bridging organizations provided over $50 \%$ of the connections (Table 1). Although these seven organizations were the most connected in the study area, this did not translate into high connectivity in the region. This result speaks to the disjointed nature of water quality management throughout the Montérégie, while at the same time offering insight for how the most connected bridging organizations could strategically improve regional connectivity. For example, bridging 
Fig. 4. Municipalities exhibit a wide range of collaborative behavior. The range includes municipalities that are not connected to others, through to municipalities that are connected to several bridging organizations and other municipalities. Yellow indicates the number of collaborations a municipality reported with government agencies, blue demonstrates the number of collaborations a municipality reported with nongovernmental organizations, and red indicates the number of collaborations municipalities have with other municipalities. This figure demonstrates that municipalities maintain both a range in collaborative behavior, as well as collaboration with a diversity of actor group types, i.e., government, NGO, municipality.

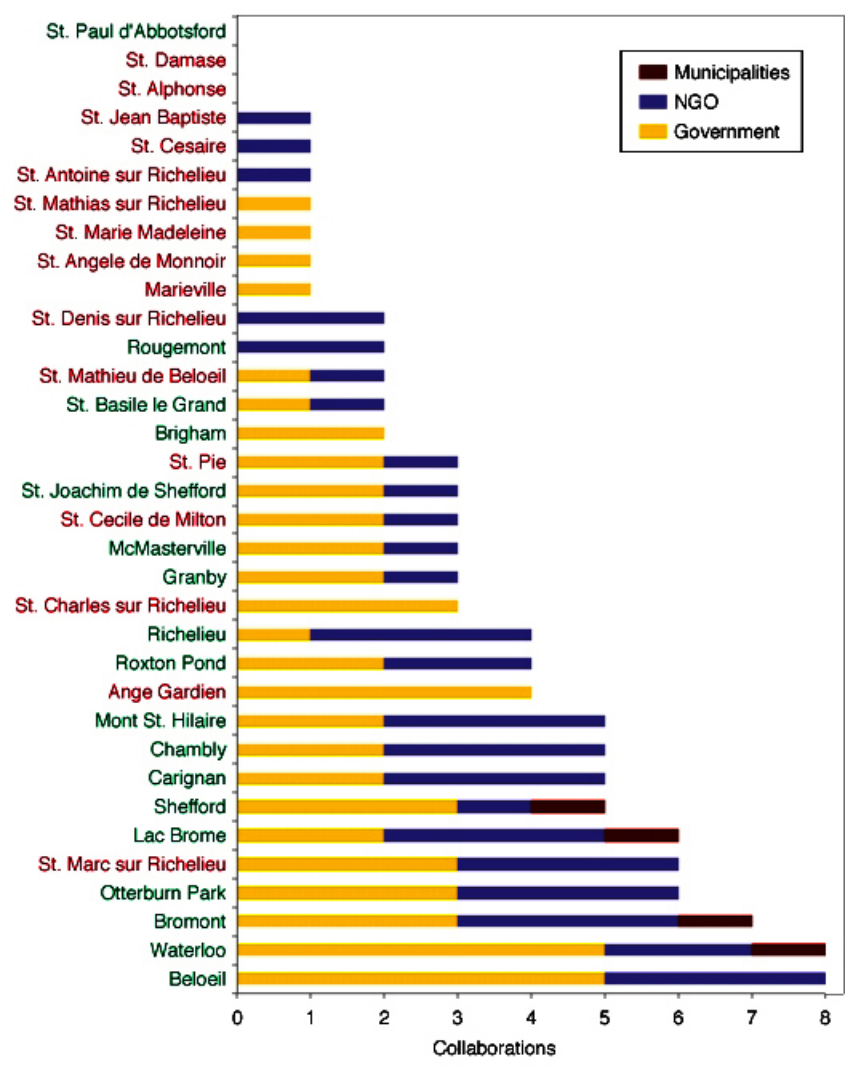

organizations could collaborate more with disconnected municipalities. We describe (Table 2) the mandates of several of the most connected bridging organizations, their pattern of connection, and municipal attitudes toward these organizations as revealed during interviews.

The most connected organization was the Québec Ministry of Sustainable Development, Environment and Parks (in French Ministère du Développement durable, de l'Environnement et
Parcs or MDDEP). It was not surprising that the MDDEP has the most collaborative connections in the network because it has a provincial mandate to support and enforce municipal action regarding water quality management (Government of Québec 2002). However, the MDDEP did not connect to most municipalities. Figure 5a shows that the majority of the municipalities (21 of 34) do not report collaboration with this provincial agency. Comments from municipalities in interviews provide possible reasons for this lack of collaboration. Municipal directors stated they lacked trust in this large government agency and they perceived that MDDEP policies were not sensitive to their local context, and the MDDEP was unwilling to engage in dialogue with them. This lack of trust in the MDDEP likely impedes its ability to connect with the region, and improving its relationship with municipalities could be an important step toward improving connectivity for water management in the region (Pretty and Ward 2001, Pretty 2003).

Fig. 5. Key bridging organizations. a) The most central bridging organization in our case study is the Provincial Ministry of the Environment (MDDEP). b) MRCs are regional government organizations, whose French name tralates to Municipal Regional Counties, in our study areas, and they partially connect their regions. c) Networks with NGOs Conseil de la Gestion du Bassin Versant De La Yamaska (COGEBY) and Comité de Concertation et de Valorization de la Rivière (COVABAR) are important bridging organizations with mandates to improve and protect water quality in each basin. A gray line divides the basins. d) The Nature Center of Mont-Saint-Hilaire is a regional NGO that focuses on Mont-Saint-Hilaire, a forested mountain in the region. It is a key bridging organization in the water quality management network.
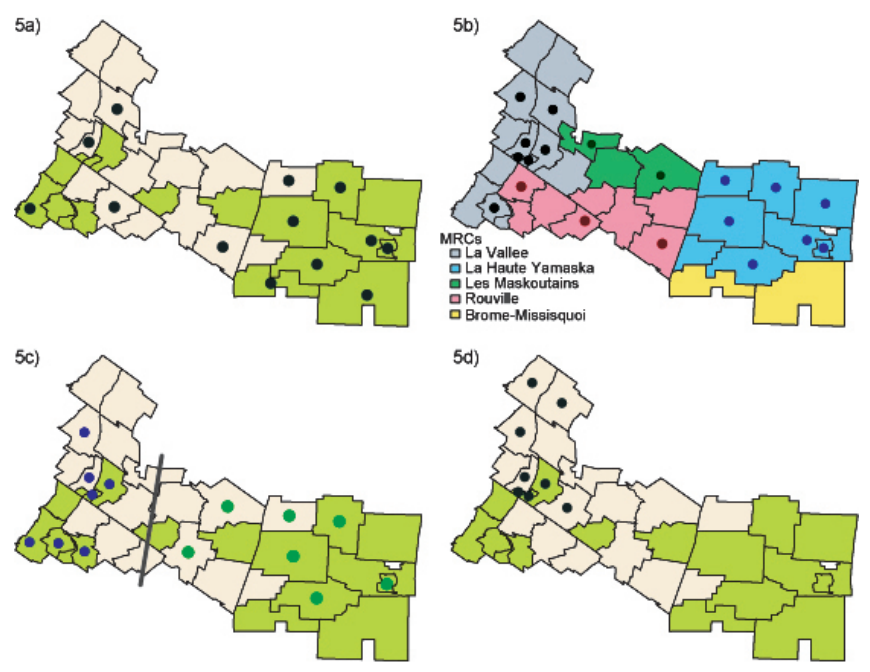
Table 1. Organizations that collaborate with municipalities on water quality management.

\begin{tabular}{|c|c|c|c|c|c|}
\hline Actor Group & English name & $\begin{array}{l}\text { Organization } \\
\text { type }\end{array}$ & $\begin{array}{c}\text { Collaborations } \\
\text { with } \\
\text { municipalities }\end{array}$ & $\begin{array}{c}\text { Collaborations } \\
\text { with agricultural } \\
\text { municipalities }\end{array}$ & $\begin{array}{c}\text { Collaborations } \\
\text { with tourism } \\
\text { municipalities }\end{array}$ \\
\hline MDDEP & Ministry of sustainable development & Government & 13 & 5 & 8 \\
\hline Centre MSH & The Nature Center of Mount Saint Hilaire & NGO & 8 & 5 & 3 \\
\hline COGBY & Organization of the Yamaska Watershed & NGO & 7 & 3 & 4 \\
\hline COVABAR & Organization of the Richelieu watershed & NGO & 7 & 2 & 5 \\
\hline MRC la Haute Yamaska & Municipal Regional Council of High Yamaska & Government & 7 & 1 & 6 \\
\hline MRC la Vallee du Richelieu & $\begin{array}{l}\text { Municipal Regional Council of Richelieu } \\
\text { Valley }\end{array}$ & Government & 7 & 3 & 4 \\
\hline Nature action Québec & Nature Action Québec & NGO & 6 & 1 & 5 \\
\hline CREM & $\begin{array}{l}\text { Montérégie Regional Committee for the } \\
\text { Environment }\end{array}$ & Government & 5 & 2 & 3 \\
\hline Nature conservancy & The Nature Conservancy of Canada & NGO & 5 & 1 & 4 \\
\hline MAPAQ & Ministry of Fishing and Agriculture & Government & 4 & 1 & 3 \\
\hline MRNF & Ministry of Natural Resources & Government & 4 & 0 & 4 \\
\hline MRC Rouville & Municipal Regional Council Rouville & Government & 3 & 3 & 0 \\
\hline BAPE $(Q)$ & Public office for the environment in Québec & Government & 3 & 1 & 2 \\
\hline MRC Les Maskoutains & $\begin{array}{l}\text { Municipal Regional Council of the } \\
\text { Maskoutains }\end{array}$ & Government & 2 & 2 & 0 \\
\hline Ministaire des affairs municipal & Ministry of Municipal Affairs & Government & 2 & 2 & 0 \\
\hline UPA & Agricultural Producers Union & NGO & 2 & 2 & 0 \\
\hline Bureau delegues & Delegates Office & Government & 2 & 1 & 1 \\
\hline MRC Brome-Missisquoi & Municipal Regional Council Brome-Missisquoi & Government & 2 & 0 & 2 \\
\hline CPTAQ & $\begin{array}{l}\text { Commission for the protection of Agricultural } \\
\text { Land in Québec }\end{array}$ & Government & 2 & 2 & 0 \\
\hline CMM & Metropolitan Community of Montréal & Government & 2 & 1 & 1 \\
\hline Amis du Lac Waterloo & Friends of Lake Waterloo & NGO & 2 & 0 & 2 \\
\hline Renaissance Lac Brome & Renaissance Brome Lake & NGO & 1 & 0 & 1 \\
\hline Les amis du Lac Bromont & Friends of Lake Bromont & NGO & 1 & 0 & 1 \\
\hline $\begin{array}{l}\text { Les amis de la tourbière de Saint- } \\
\text { Joachim }\end{array}$ & Friend of the wetland of Saint-Joachim & NGO & 1 & 0 & 1 \\
\hline $\begin{array}{l}\text { Fondation Des Terre De Lac } \\
\text { Brome }\end{array}$ & Land Foundation of Lake Brome & NGO & 1 & 0 & 1 \\
\hline Le Corridor appalachien & Appalachian Corridor & NGO & 1 & 0 & 1 \\
\hline Committee du Lac Roxton Pond & Lake committee of Roxton Pond & NGO & 1 & 0 & 1 \\
\hline $\begin{array}{l}\text { Association environmental du St. } \\
\text { Basil }\end{array}$ & Environmental association of Saint Basil & NGO & 1 & 0 & 1 \\
\hline SHECRC & $\begin{array}{l}\text { Horticulture and ecological society of } \\
\text { Chambly, Richelieu, and Carignan }\end{array}$ & NGO & 1 & 0 & 1 \\
\hline APDDMR & $\begin{array}{l}\text { Association for the Protection and } \\
\text { Development of Mount Rougemont }\end{array}$ & NGO & 1 & 0 & 1 \\
\hline
\end{tabular}

Another set of organizations that provided substantial connectivity in our study area were Municipal Regional Councils (MRCs). In Québec MRCs are regional level government organizations made up of the municipalities they contain. Each MRC has a mandate to support and enforce water quality management; therefore we were surprised by the number of municipalities in each MRC that did not collaborate on water quality management issues with the MRC to which they belonged (Fig. 5b). Interviewees varied in their attitude and engagement with the MRCs. Some municipalities reported a dependency and confidence in the MRC as an agency to address and support water quality management in their jurisdiction, whereas other municipalities had little confidence that their MRC could provide them support and opportunities for collaboration with other municipalities. This variance is evident in Figure 5b, showing the extent to which MRCs collaborated with the municipalities in their jurisdiction regarding water quality management. For example, in the east, the MRC La Haute Yamaska collaborated with six municipalities, however it did not collaborate with SaintAlphonse. Like the MDDEP, our results indicated that the MRC, as a government agency, did not maintain evenly distributed collaborative efforts across the landscape. In fact, often it was the same municipalities, for example SaintAlphonse, that reported no collaboration with the MDDEP and the MRC.

Two of the most connected NGOs, Conseil de gestion du bassin versant de la Yamaska (COGEBY) and Comité de concertation et de valorisation du bassin de la Rivière (COVABAR), were established and are funded by the 
Table 2. Main bridging organizations, their mandates, and connections.

\begin{tabular}{|c|c|c|c|}
\hline Organization & Org. Type & Water related mandate & $\begin{array}{c}\text { Number of } \\
\text { collaborations with } \\
\text { municipalities }\end{array}$ \\
\hline $\begin{array}{l}\text { Ministry of Sustainable Development, } \\
\text { Environment,, and Parks (MDDEP) }\end{array}$ & Gov. & To protect the environment & 13 \\
\hline $\begin{array}{l}\text { The Nature Center of Mont-Saint-Hilaire } \\
\text { (Centre MSH) }\end{array}$ & NGO & $\begin{array}{l}\text { 1. To assure over the short and long term conservation of Mont- } \\
\text { Saint-Hilaire } \\
\text { 2. To offer educational and cultural activities that allow all citizens } \\
\text { to experience nature } \\
\text { 3. To promote conservation of the natural spaces of the region }\end{array}$ & 8 \\
\hline $\begin{array}{l}\text { Organization of the Yamaska Watershed } \\
\text { (COGBY) }\end{array}$ & NGO & To improve the water quality of the Yamaska water basin & 7 \\
\hline $\begin{array}{l}\text { Organization of the Richelieu Watershed } \\
\text { (COVABAR) }\end{array}$ & NGO & $\begin{array}{l}\text { 1. To develop an ecosystem approach to management of the water } \\
\text { basin } \\
2 \text {. To educate and inform citizens about decisions relevant to the } \\
\text { water basin } \\
\text { 3. To promote citizens' access to the watershed }\end{array}$ & 7 \\
\hline Municipal Regional Council of Richelieu Valley & Gov. & To support the management of water & 7 \\
\hline Municipal Regional Council of High Yamaska & Gov. & $\begin{array}{l}\text { 1. Address the blue-green algae problem in the region's rivers and } \\
\text { lakes. } \\
2 \text {. To create permanent management of the territories water. }\end{array}$ & 7 \\
\hline Municipal Regional Council Rouville & Gov. & $\begin{array}{l}\text { 1. To manage water in the jurisdiction } \\
\text { 2. To implement regulations surrounding water management in } \\
\text { municipalities }\end{array}$ & 3 \\
\hline Municipal Regional Council Brome-Missisquoi & Gov. & $\begin{array}{l}\text { 1. To maintain and repair waterways } \\
\text { 2. To intervene in water management when necessary }\end{array}$ & 2 \\
\hline Municipal Regional Council Les Maskoutains & Gov. & To manage the rivers in all the municipalities of its territory & 2 \\
\hline
\end{tabular}

provincial government to act as watershed bridging organizations. However, similar to organizations discussed above, these watershed organizations did not collaborate with all the municipalities within their respective watersheds and collaborated less with the agricultural municipalities who disproportionately pollute water. Agricultural municipalities such as Saint-Denis-sur-Richelieu in the northwest section of the study site, or Saint-Damase and Ange-Gardian located in the center of the study site, did not collaborate with Québec's governmental agencies or with these watershed organizations.

The most connected NGO in our study was the Nature Center of Mont-Saint-Hilaire. It connected a cluster of municipalities in the west of our study region surrounding Mont-Saint-Hilaire (Fig. 5d). The Nature Center collaborated beyond the area of the mountain, and worked with more agricultural municipalities than tourism municipalities, a trend unique to this bridging organization (Fig. 5d). Our study site contained three municipalities with forested mountains, but only MontSaint-Hilaire maintained a network among the municipalities that surround it.

\section{Social-ecological heterogeneity: agriculture vs. tourism}

The types of ecosystem services produced in a municipality were strongly related to its pattern of collaboration. The only two direct collaborative ties between municipalities were between tourism municipalities. Tourism municipalities had approximately twice the number of collaborations with bridging organizations than agricultural municipalities (4.12 vs. 2.24, t-test, $\mathrm{P}<0.01$ ). This pattern was driven by tourism municipalities reporting more than twice as much collaboration with nongovernmental organizations than agricultural municipalities $(1.88$ vs. $0.82, \mathrm{P}<0.01)$. There was no significant difference in collaboration between agricultural and tourism municipalities for governmental organizations. Of the most central bridging organizations (Table 1), only the Mont-Saint-Hilaire Nature Center had more collaboration with agricultural municipalities than tourism municipalities.

Tourist municipalities performed more total activities than agricultural municipalities $(15.59$ vs. $12.59, \mathrm{P}<0.06)$. Tourist municipalities also performed more initiative-based activities than their agricultural counterparts (5.18 vs. 3.24 , $\mathrm{P}<0.05)$. There was no significant difference in the activities performed alone by the two groups.

\section{Networks and management activities}

Municipal engagement in water quality management activities varied enormously between municipalities. The municipality most engaged in water quality management activities reported 23 activities, whereas the least engaged reported only three activities (Appendix 2). Unlike collaborative links, municipal management activities were not significantly spatially clustered (Fig. 6). 
The total number of collaborations a municipality had was robustly correlated with a municipality's number of water quality management activities. Collaborative ties were positively correlated with the total number of management activities a municipality performed alone (total activities alone; $\mathrm{R}=0.596, \mathrm{P}<0.001$ ), the number of initiative-based activities a municipality performed alone (total initiativebased activities alone; $\mathrm{R}=0.670, \mathrm{P}<0.0001$ ), and with the total number of water quality management activities (total activities; $\mathrm{R}=0.701, \mathrm{P}<0.0001)$.

Fig. 6. a) Water quality management activities across the landscape. The size of the circles indicates the total number of water quality management activities done by each municipality. Municipalities oriented toward agricultural production are shaded pink, tourism oriented municipalities are shaded green, water bodies are shaded light blue, and rivers are edged in black. b) The number of collaborations a municipality has is correlated with its engagement in water management activities.

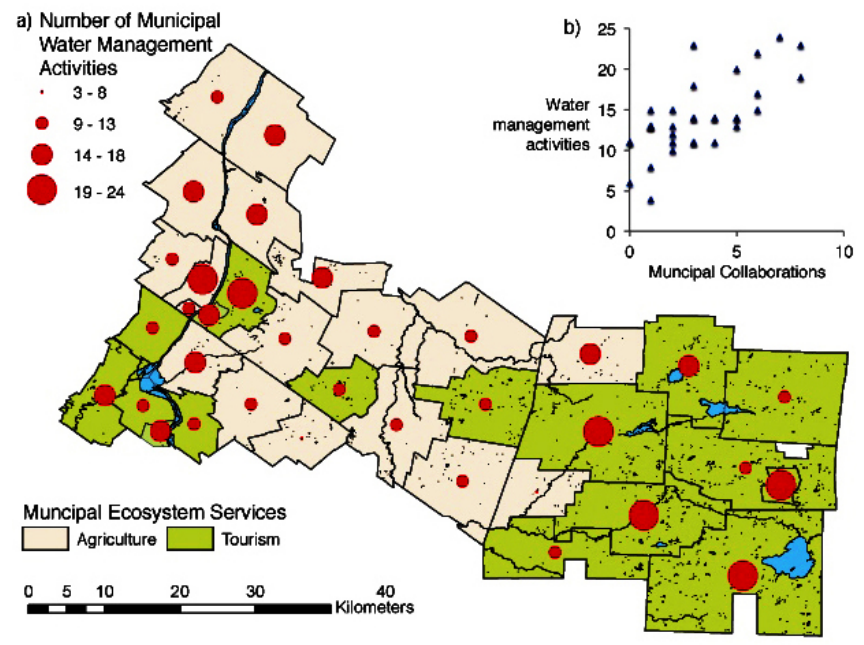

The hierarchical partitioning analysis also robustly demonstrated that a municipality's collaborations had the largest, and most consistent, effect on total number of activities a municipality performs; the number of management activities a municipality performs alone; and the number of initiativebased activities a municipality performs alone. Independent variation in total activities was $24 \%$ explained by total collaborations, and $14 \%$ by average family income. Independent variation in activities initiated by a municipality was $27 \%$ explained by total collaborations, and $12 \%$ by whether a municipality viewed water quality as one of their largest problems. Independent variation in activities conducted by a municipality alone was $22 \%$ explained by total collaborations, and $14 \%$ by average family income. Water quality, proportion of cropland, perceived regional and "municipal importance of algae in water," and "setting of goals for water quality" had no significant effect on the number of activities conducted in a municipality.

\section{DISCUSSION}

Contrary to our expectation that municipalities would directly collaborate with their neighbors and other municipalities that shared their orientation toward agriculture or tourism, we found that direct intermunicipal collaboration was rare. Instead, municipalities were indirectly connected, in twomode networks, via bridging organizations.

Agricultural and tourism municipalities differed in their connections to bridging organizations and engagement in water management activities. Tourism municipalities were twice as connected as agriculturally oriented municipalities to bridging organizations, and agricultural municipalities were engaged in fewer water quality management activities. In other words, agricultural areas were less connected and less engaged in activities to improve water. That there is not a more integrated network is not surprising, in that water quality problems in this region are not resolved. However, it is interesting that the ecosystem service orientation of the municipality explains so much of the variation. The fact that bridging organizations work the least with municipalities who pollute the water most likely contributes to the inability of the region to solve their shared water quality problems (van Bueren et al. 2003, Head 2008). This disconnection between agriculture and tourism is particularly important in the Montérégie because agricultural municipalities produce most of the water problems. Both governmental and nongovernmental bridging organizations are failing to bridge the agricultural-tourism divide, but rather they are connecting similar municipalities to one another. We are unable to identify whether this difference is driven by the bridging organizations, the municipalities, or is due to their interaction.

Our research suggests that differences in collaboration are related to differences in water management. Researchers have suggested social networks among actors/actor groups enhance resource management (Crona and Bodin 2006, Lubell and Fulton 2008, Bodin and Crona 2009) and our results support this relationship. Our statistical analysis revealed that collaborative ties in social networks robustly predicted water management activities conducted alone or in collaboration, as well as activities mandated by law or undertaken under a municipal initiative. Furthermore, hierarchical portioning tests showed that the number of collaborations better explained variation in water management activities than the demographic properties of a municipality or the views of a municipality on water quality. While our results do not demonstrate that network links cause water management activities, or vice versa, they do show the two are found together. A study of the relationships between network dynamics and water management activities over time may be 
able to unravel causation, but we expect that causation is complex, with collaboration in social networks and engagement in activities mutually reinforcing one another.

\section{Implications of results for the Montérégie region}

The Montérégie has a water quality problem that is not being solved. Poor water quality has resulted in lake closures and significantly impacted the tourism industry. Furthermore, water quality in several rivers is below regulatory standards (Raudsepp-Hearne et al. 2010). A formally articulated goal of many organizations in the region is to improve its poor water quality (Government of Québec 2002), however, to date these efforts have only been partially successful.

Water quality management activities can improve the quality of water, and our results show that engagement in water quality management activities is strongly related to engagement in collaborations with bridging organizations. This result suggests that the strategy of creating and funding bridging organizations has likely contributed to an increase in water management activity because of increased collaboration among municipalities. However, the connections to bridging organizations largely mirror the social-ecological heterogeneity of the region rather than bridging conflicting user groups.

We identified three types of weaknesses in the region's collaborative water management network. The presence of these weaknesses suggests there is room for improving the network, which may further improve water quality management. First, we found that there were gaps as well as weak connections in the network among municipalities. Some municipalities were neither connected directly nor indirectly to other municipalities. We found a striking absence of direct collaborations between municipalities (only 4 out of 34). Second, we found that much of the networking for water quality management was not very robust. Many municipalities were only weakly connected to other municipalities because they were connected via bridging organizations that they did not trust, and they lacked alternative links to help them connect to other municipalities. Third, we found NGOs, with the exception of the Mont-Saint-Hilaire Nature Centre, collaborated much more with tourism municipalities. This tendency is reinforcing problematic social-ecological divisions in the landscape. Although municipal engagement in collaborations is not, by itself, sufficient to solve water quality problems, without such expanded networks, which include all municipalities and enable coordination, effective water management within the region is likely to remain limited (Ostrom 1991, Ostrom et al. 1999).

Our results demonstrate that water management activities are highly correlated with collaborative ties and suggest that improving water management collaborations could yield further improvements in water quality. Based on our analysis we advise three overlapping strategies to address weaknesses in the water management network. To begin with, government organizations could try to improve the quality of the relationship between municipal and larger scale government organizations. This would improve the number of municipalities these organizations collaborate with and the quality of their collaborations. As well, NGOs could increase their efforts to build collaboration with more municipalities, with a goal to strengthen connections with agricultural municipalities specifically. The particular success of the Mont-Saint-Hilaire Nature Centre in bridging multiple types of municipalities suggests that this organization could be a model for others. Lastly, municipalities could work more with one another. These connections could be encouraged by bridging organizations, as well as by increased technical, administrative, social, or financial support to municipalities.

The current clustering of direct collaborations, indirect collaborations, and collaboration gaps, suggests that a targeted water management strategy could be expanded from existing hotspots of effective municipal water management to the unconnected, or weakly connected municipalities. This may prove to be the most effective strategy for generally increasing management activities in the watershed. Such an approach could build on existing successes while disrupting the observed pattern of the more densely connected networks in tourism areas only. An alternate approach would be to focus efforts and resources on the municipalities disconnected from the water quality management network.

Building regional water management collaborations would be expedited if all concerned parties understood the local barriers to the formation of such networks. We suggest three areas for further investigation about network formation. First, it would be useful to understand the reasons for the existing sparse connections among municipalities, by discovering what factors drive engagement of organizations and municipalities in water management collaborations. By gaining a better understanding of why municipalities remain disconnected, more effective strategies can be employed to connect actor groups across watersheds. Second, understanding the social, economic, or cultural factors that cause differences in connectivity between agricultural and tourism municipalities would assist bridging organizations to design strategies for developing a more collaborative water quality network that explicitly targets the division between agriculture and tourism. Third, by studying which management activities most improve water quality and testing how the establishment, or loss, of collaborative links over time influences employment of effective water management strategies, watershed actor groups could identify robust approaches to best improve water management.

\section{Research frontiers beyond the Montérégie}

Our research makes three contributions to the study of social networks in social-ecological systems that we believe can be used to advance social-ecological research. First, we 
demonstrate that social network structure, specifically the number of collaborations, is correlated with the extent of engagement in management activities. Second, we demonstrate that the distribution of ecosystem services is related to the shape of social network structure. Third, our work confirms the importance of bridging organizations in creating connectivity across regions, but shows that connections forged via bridging organizations can leave substantial gaps in regional networks.

Although many researchers have investigated the important relationship between social network structure and various criteria of management success (Provan and Milward 2001, Sandström and Carlsson 2008, Scholz et al. 2008), there has been less attention paid to how the ecological context of social networks shapes their form (Pahl-Wostl 2009, Lubell et al. 2002). A social-ecological approach to social networks requires testing both how a social network performs and how a network varies with its ecological context. Our strategy of relating network structure to ecosystem services and ecological management activities provides one approach to combining the social and ecological (Fig. 1) that could be applied to other cases.

Diversity in social-ecological landscapes builds resilience, but complicates management. In our study, social networks, water management, and ecosystem service use are unevenly distributed across the landscape. This diversity contributes to resilience, by providing multiple forms of diversity to cope with and adapt to change (Peterson et al. 1998). However, we found that this diversity also impeded integrated water management, because different ecosystem service users remained unconnected. Our research suggests the inclusion of social-ecological heterogeneity in analysis of regional management would be useful for detecting barriers to integrated management, and may help discover solutions that allow both integrated management and social-ecological landscape diversity.

Bridging organizations can coordinate action to produce integrated management without depleting social-ecological diversity. By connecting diverse watershed actors, e.g., agricultural and tourism based municipalities, bridging organizations can facilitate the coordinated and consistent management of shared resources (Cash et al. 2006, Berkes 2007, Olsson et al. 2007). In theory, bridging organizations are well suited for such a task because they span watershed regions and provide a common mechanism for coordinating the efforts of municipalities that may not work directly together. However, in the Montérégie, connections to bridging organizations are structurally biased by the social-ecological properties of the landscape. We show that bridging organizations in the Montérégie connect more frequently with tourist municipalities than agricultural municipalities, thereby working the least with municipalities that pollute water the most. This orientation also creates network 'hotspots' whereby municipalities in particular areas of the landscape maintain a disproportionately high number of collaborations with a variety of bridging organizations. This tendency reinforces social-ecological heterogeneity rather than coordinating action between conflicting user groups. This result suggests that research on bridging organizations that considers their social-ecological properties may reveal social-ecological gaps and hotspots within their networks.

\section{CONCLUSIONS}

Our research shows the value of considering the socialecological context of social networks. We posed three questions on the relationship between social networks, management, and ecosystem services in the Montérégie, and answered them by linking social networks to water management and ecosystem service use. We discovered that, contrary to our expectations, networks between municipalities were rarely established directly between neighbors, but were primarily indirect via governmental and nongovernmental bridging organizations. However, even those bridging organizations only partially connected the municipalities of the region, leaving many municipalities weakly connected and some completely isolated. This lack of connection appears to be important because we found the connectedness of municipalities was positively correlated with their engagement in water quality management activities, both individually and in collaboration with others. Finally, we discovered that the ecosystem service type of a municipality, tourism or agricultural, was strongly related to network structure, showing that tourism municipalities were more connected to one another and to bridging organizations than agricultural municipalities were.

In combination these findings revealed an ecosystem service divide within the water management network in the Montérégie and allowed us to identify collaborative hotspots and gaps within this landscape. These results suggest using strategies for building collaboration that best fit the socialecological structure of the landscape, and also suggest that a social-ecological approach can improve the analysis of social networks in natural resource management.

Responses to this article can be read online at: http://www.ecologyandsociety.org/voll7/iss2/art24/ responses/

\section{Acknowledgments:}

We would like to thank all the people in the Montérégie who were willing to talk about their work with us. This paper benefited from discussions with Ciara Raudsepp-Hearne, Maria Tengö, Beatrice Crona, Örjan Bodin, and Steven Alexander. Maria Tengö also helped with interviews in 
Québec, and Ciara Raudsepp-Hearne allowed us to use her ecosystem service data. We thank the Canada Research Chairs program for funding. Stockholm Resilience Centre is supported by a grant from MISTRA. Furthermore, the efforts of two anonymous reviewers greatly improved the manuscript.

\section{LITERATURE CITED}

Berkes, F. 2007. Community-based conservation in a globalized world. Proceedings of the National Academy of Sciences 104:15188-15193.

Bodin, Ö., and B. I. Crona 2009. The role of social networks in natural resource governance: what relational patterns make a difference? Global Environmental Change 19:366-374. htt p://dx.doi.org/10.1016/j.gloenvcha.2009.05.002

Borgatti, S. P., A. Mehra, D. J. Brass, and G. Labianca. 2009. Network analysis in the social sciences. Science 323:892-895. http://dx.doi.org/10.1126/science.1165821

Butts, C. T. 2005. Tools for social network analysis. Version 1.5. University of California-Irvine, Irvine, California, USA. [online] URL: http://erzuli.ss.uci.edu/R.stuff/

Carpenter, S. R., N. F. Caraco, D. L. Correll, R. W. Howarth, A. N. Sharpley, and V. H. Smith. 1998. Nonpoint pollution of surface waters with phosphorous and nitrogen. Ecological Applications 8:559-568. http://dx.doi.org/10.1890/1051-0761 (1998)008[0559:NPOSWW]2.0.CO;2

Cash, D. W., W. N. Adger, F. Berkes, P. Garden, L. Lebel, P. Olsson, L. Pritchard, and O. Young. 2006. Scale and crossscale dynamics: governance and information in a multilevel world. Ecology and Society 11(2): 8. [online] URL: http://ww w.ecologyandsociety.org/vol11/iss $2 / \operatorname{art} 8 /$

Chevan, A., and M. Sutherland. 1991. Hierarchical partitioning. American Statistician 45:90-96.

Coleman, J. S. 1990. Foundations of social theory. Harvard University Press, Cambridge, Massachusetts, USA.

Crona, B., and Ö. Bodin. 2006. What you know is who you know? Communication patterns among resource users as a prerequisite for co-management. Ecology and Society 11(2): 7. [online] URL: http://www.ecologyandsociety.org/voll1/iss $2 /$ art7l

Delisle, F., S. Gariépy, and Y. Bédard. 1998. Bassin versant de la rivière Yamaska: l'activité agricole et ses effets sur la qualité de l'eau. Ministère de l'Environnement et de la Faune et Saint-Laurent Vision 2000, Québec, Québec, Canada.

Gangbazo, G., and F. Babin. 2000. Pollution de l'eau des rivières dans les bassins versants agricoles. Vecteur Environnement 33:47-57.

Government of Québec. 2002. Politique National de L'eau. L'eau. La Vie. L'avenir. Ministère du Développement durable, de l'Environnement et des Parcs, Québec, Québec, Canada. [online] URL: http://www.mddep.gouv.qc.ca/eau/politique/

Head, B. W. 2008. Assessing network-based collaborations. Public Management Review 10:733-749. http://dx.doi.org/10 $.1080 / 14719030802423087$

Imperial, M. T. 2005. Using collaboration as a governance strategy: lessons from six watershed management programs. Administration \& Society 37:281-320. http://dx.doi.org/10.11 77/0095399705276111

Ison, R., N. Röling, and D. Watson. 2007. Challenges to science and society in the sustainable management and use of water: investigating the role of social learning. Environmental Science \& Policy 10:499-511 http://dx.doi.org/10.1016/j.envs ci.2007.02.008

Leggett, C., and N. Bockstael. 2000. Evidence of the effects of water quality on residential land prices. Journal of Environmental Economics and Management 39:121-144. htt p://dx.doi.org/10.1006/jeem.1999.1096

Lin, N. 2001. Social capital: a theory of social structure and action. Cambridge University Press, Cambridge, UK.

Lubell, M., and A. Fulton. 2008. Local policy networks and agricultural watershed management. Journal of Public Administration Research and Theory 18:673-696. http://dx.do i.org/10.1093/jopart/mum031

Lubell, M., M. Schneider, J. T. Scholz, and M. Mete. 2002. Watershed partnerships and the emergence of collective action institutions. American Journal of Political Science 46:148-163. http://dx.doi.org/10.2307/3088419

MacNally, R. 2002. Multiple regression and inference in ecology and conservation biology: further comments on identifying important predictor variables. Biodiversity and Conservation 11:1397-1401. http://dx.doi.org/10.1023/A:101 $\underline{6250716679}$

MacNally, R., and C. J. Walsh. 2004. Hierarchical partitioning public-domain software. Biodiversity and Conservation 13:659-660. http://dx.doi.org/10.1023/B:BIOC.0000009515.1 $\underline{1717.0 \mathrm{~b}}$

Marín, A. and F. Berkes. 2010. Network approach for understanding small-scale fisheries governance. The case of the Chilean coastal co-management system. Marine Policy 34:851-858. http://dx.doi.org/10.1016/j.marpol.2010.01.007

Mimeault, M. 2002. Mise en valeur de la Baie Missisquoi et du Lac Champlain. Agrosol 13:92-96.

Newig, J., D. Günther, and C. Pahl-Wostl. 2010. Synapses in the network: learning in governance networks in the context of environmental management. Ecology and Society 15(4): 
24. [online] URL: http://www.ecologyandsociety.org/vol15/iss4/ art24/

Newman, L. L., and A. Dale. 2005. Network structure, diversity, and proactive resilience building: a response to Tompkins and Adger. Ecology and Society 10(1): r2. [online] URL: http://www.ecologyandsociety.org/vol10/iss1/resp2/

Olsson, P., C. Folke, V. Galaz, T. Hahn, and L. Schultz. 2007. Enhancing the fit through adaptive co-management: creating and maintaining bridging functions for matching scales in the Kristianstads Vattenrike Biosphere Reserve, Sweden. Ecology and Society 12(1): 28. [online] URL: http://www.ecologyand society.org/vol12/iss 1/art28/

Ostrom, E. 1991. Governing the commons: the evolution of institutions for collective action. Cambridge University Press, Cambridge, UK.

Ostrom, E., J. Burger, C. B. Field, R. B. Norgaard, and D. Policansky. 1999. Revisiting the commons: local lessons, global challenges. Science 284:278-282. http://dx.doi.org/10. $\underline{1126 / \text { science.284.5412.278 }}$

Pahl-Wostl, C. 2009. A conceptual framework for analysing adaptive capacity and multi-level learning processes in resource governance regimes. Global Environmental Change 19:354-365. http://dx.doi.org/10.1016/j.gloenvcha.2009.06.001

Pahl-Wostl, C., and N. Kranz. 2010. Water governance in times of change. Environmental Science \& Policy 13:567-570. http://dx.doi.org/10.1016/j.envsci.2010.09.004

Peterson, G. D., C. R. Allen, and C. S. Holling. 1998. Ecological resilience, biodiversity, and scale. Ecosystems 1:6-18. http://dx.doi.org/10.1007/s100219900002

Pretty, J. 2003. Social capital and the collective management of resources. Science 302:1912-1914. http://dx.doi.org/10.1126/ science. 1090847

Pretty, J., and H. Ward. 2001. Social capital and the environment. World Development 29:209-227. http://dx.doi.o rg/10.1016/S0305-750X(00)00098-X

Provan, K. G., and P. Kenis. 2008. Modes of network governance: structure, management, and effectiveness. Journal of Public Administration Research and Theory 18:229-252. http://dx.doi.org/10.1093/jopart/mum015

Provan, K. G., and H. B. Milward. 2001. Do networks really work? A framework for evaluating public-sector organizational networks. Public Administration Review 61 (4):414-423. http://dx.doi.org/10.1111/0033-3352.00045

R Development Core Team. 2010. R: a language and environment for statistical computing. R Foundation for Statistical Computing, Vienna, Austria.
Raudsepp-Hearne, C., G. D. Peterson, and E. M. Bennett. 2010. Ecosystem service bundles for analyzing tradeoffs in diverse landscapes. Proceedings of the National Academy of Sciences 107:5242-5247. http://dx.doi.org/10.1073/pnas.0907 $\underline{284107}$

Ripl, W. 2003. Water: the bloodstream of the biosphere. Philosophical Transaction of the Royal Society of London B 358:1921-1934. http://dx.doi.org/10.1098/rstb.2003.1378

Sandström, A., and L. Carlsson. 2008. The performance of policy networks: the relation between network structure and network performance. Policy Studies Journal 36:497-524. http://dx.doi.org/10.1111/j.1541-0072.2008.00281.x

Schneider, M., J. Scholz, M. Lubell, D. Mindruta, and M. Edwardsen. 2003. Building consensual institutions: networks and the National Estuary Program. American Journal of Political Science 47:143-158. http://dx.doi.org/10.1111/1540 $\underline{-5907.00010}$

Scholz, J. T., R. Berardo, and B. Kile. 2008. Do networks solve collective action problems? Credibility, search, and collaboration. Journal of Politics 70:393-406. http://dx.doi.or $\mathrm{g} / 10.1017 / \mathrm{S} 0022381608080389$

Scott, J. 2000. Social network analysis: a handbook. Second Edition. Sage, London, UK.

van Bueren, E. M., E.-H. Klijn, and J. F. M. Koppenjan. 2003. Dealing with wicked problems in networks: analyzing an environmental debate from a network perspective. Journal of Public Administration Research and Theory 13:193-212. http ://dx.doi.org/10.1093/jopart/mug017

Wasserman, S., and K. Faust. 1994. Social network analysis: methods and applications. Cambridge University Press, Cambridge, UK. 


\section{APPENDIX 1: INTERVIEW SURVEY}

Translated into English with French in italics

Municipality Municipalité

Date Date

Name :Personne Interviewé(e)

1. What is your role in the Municipality? Quel est votre rôle (votre titre) dans votre municipalité?

2. What are, in your opinion, the principal resources or attributes of your municipality? For example, what would attract someone from Montreal to move here? What keeps your residence here? Quelles sont, selon vous, les principales ressources, ou les avantages de votre municipalité ? Par example, qu'est-ce qui attirerait quelqu'un de Montréal et lui donnerait le gout de déménager dans votre municipalité ? Qu'est-ce qui retient vos résidents dans votre municipalité ?

3. More specifically, are there resources or attributes your municipality has that are dependant on the physical environment? Y a-t-il des ressources/ avantages qui soient reliés a l'environnement physique?

4. How do you develop or protect those resources? Comment soutenez-vous le développement ou protegez-vous ces ressources?

5. What are the principal environmental problems for your municipality? Quels sont les principales problématiques environnementales dans votre municipalité?

6. a) In your municipality the people that work with management of water quality, do they integrate with people who work on agricultural management? Dans votre municipalité, les personnes qui s'occupent de la gestion de la qualité de l'eau interagissent-elles avec celles qui sont responsables des gestions agricoles?

$\mathbf{Y}$

\section{$\mathbf{N}$}

b) If the response to 1a) is yes : Si la réponse de la) est oui: Given the categories below, which best describes these interactions? Parmi les énoncés suivants, lequel décrit le mieux ces interactions? Par example?

\begin{abstract}
We hold friendly relations, but it is not necessary to work together $\mathrm{On}$ entretient des
\end{abstract}

We share
information and
experiences On
partage des
informations et les

We work together to establish rules and to develop strategic management plans
We collaborate to organize joint activities and on common projects On collabore pour 
relations amicales, mais ce n'est pas

nécessaire de

traviller ensemble expériences

On travaille ensemble pour établir les règles municipales, et pour développer les plans de gestion stratégique de la municipalité organiser des activités conjointes, on collabore sur des projets en commun

7. a) Do you do activities or follow rules related to water quality? Est-ce-que vous faitez les activities (ou réagles) qu' implique de l'environment la quality de l'eau

b) Do you integrate with other municipalities in the region concerning water quality? Interagissez-vous avec autres municipalités de la région concernant l'environment? (le sujet de la qualité de l'eau? )

c) With who exactly? avec qui exactement? And how would you characterise your relations? et comment vouliez-vous caractérise votre interaction?

(Given the descriptions below, chose the one that best characterises your interactions with the other municipalities in the last five years and on the subject of agricultural management and/ or water quality management) (Parmi les énoncés suivants, choisissez celui qui caractérise le mieux les interactions que votre municipalité a entretenu avec celles-ci au cours des derniers 5 années (spécifiquement au sujet de la gestion agricole ou (et) gestion de la qualité de l'eau).

\begin{tabular}{|c|c|c|c|c|}
\hline \multirow{8}{*}{$\begin{array}{l}\text { A. } \\
\text { Municipalities } \\
\text { Municipalités }\end{array}$} & Share & \multicolumn{2}{|l|}{ Exchange } & \multirow{5}{*}{$\begin{array}{l}\text { conjointes, } \\
\text { collabore sur } \\
\text { des projets en } \\
\text { commun }\end{array}$} \\
\hline & information & Advice & & \\
\hline & Partager de & Échanges & & \\
\hline & l'information & des conseils & & \\
\hline & & $\begin{array}{l}\text { Find } \\
\text { solutions to } \\
\text { problems }\end{array}$ & & \\
\hline & Facts, events, & Trouver des & & \\
\hline & problems faits, & solutions, & Regional, & \\
\hline & $\begin{array}{l}\text { événements, } \\
\text { problématiques }\end{array}$ & $\begin{array}{l}\text { soutien } \\
\text { technique }\end{array}$ & $\begin{array}{l}\text { Provincial (régional, } \\
\text { provinciaux) }\end{array}$ & \\
\hline
\end{tabular}

Collaborate to organize joint activites and projects Collabore

Participation a des projets plus larges

pour organiser des activités conjointes, collabore sur des projets en des conseils Find solutions to problems

Facts, events, Trouver des problems faits, solutions, problématiques technique

\author{
Provincial (régional, \\ provinciaux)
}


Are there any other municipalities that you have not mentioned, that you interact or collaborate with? Y-a-t-il d'autres municipalités qui n'ont pas été mentionnées avec lesquelles vous interagissez? collaborer?

b) How would you describe your interaction with actor groups at the local scale on the subject of agricultural management and water quality management? Comment décrivezvous vous votre contact avec les acteurs sur l'échelle locale dans votre municipalité en ce qui a trait le sujet de la gestion agricole ou(et) gestion de la qualité de l'eau

\section{B. Actor} group on the local scale acteur groupe échelle local

$\begin{array}{ll}\text { Share } & \begin{array}{l}\text { Exchange } \\ \text { advice }\end{array} \\ \text { information } & \begin{array}{l}\text { Échanges des } \\ \text { Partager de }\end{array} \\ \text { l'information } & \text { conseils }\end{array}$

Find solutions to technical

Facts, events problems and problems faits, Trouver des solutions, événements, problématiques

Exchange
advice
Échanges des
conseils

Distribute government rules and regulations Circulation des avis gouvernementaux

Collaborate
Collabore
Organize joint
activities,
collaborate on
common
projects
Organiser des
activités
conjointes,
collabore sur
des projets en
commun

Put in place government rules and regulations Mis en application des règles gouvernementales

c) Given the following categories, choose the one that best characterizes your municipalities interactions with the government on the subject of water quality management. Parmi les énoncés suivants, choisissez celui qui caractérise le mieux les interactions que votre municipalité entretient avec le gouvernement au sujet de la gestion agricole ou(et) gestion de la qualité de l'eau

C.

$\begin{array}{ll}\text { Government } & \text { Share } \\ \text { Gouvernement } & \text { information }\end{array}$

Partager de

l'information

Facts, events

and problems

faits,

événements,

\section{Distribute}

government

rules and

Exchange
advice
Échanges des
conseils
Find solutions
to technical
problems
Trouver des

regulations

Circulation des

avis

gouvernementaux

Put in place

government rules

and regulations

Mis en
Collaborate

Collabore

Organize joint activities, collaborate on common 


$\begin{array}{llll}\text { problématiques } & \text { solutions, } & \text { application des } & \text { projects } \\ & \text { soutien } & \text { règles } & \text { Organiser des } \\ \text { technique } & \text { gouvernementales } & \text { activités } \\ & & \text { conjointes, } \\ & & \text { collabore sur } \\ & & \text { des projets en } \\ & \text { commun }\end{array}$

d) Do you know of environmental organizations that work in this region? Are there organizations with whom you have contact when it comes to water quality management? Est-ce que vous connaîtez les organizations environmental qui s'occuper dans cetter region? Est-ce qu'il y a les organisations spécialisées avec les quelles vous avez le contact, en ce qui concern la gestion agricole ou(et) gestion de la qualité de l'eau?

\begin{tabular}{|c|c|c|c|c|}
\hline & $\begin{array}{l}\text { Share } \\
\text { information }\end{array}$ & $\begin{array}{l}\text { Exchange } \\
\text { advice }\end{array}$ & $\begin{array}{l}\text { Distribute } \\
\text { government } \\
\text { rules and } \\
\text { regulations } \\
\text { Circulation des }\end{array}$ & \\
\hline $\begin{array}{l}\text { Organisations } \\
\text { spécialisées }\end{array}$ & $\begin{array}{l}\text { Partager de } \\
\text { l'information }\end{array}$ & $\begin{array}{l}\text { Échanges des } \\
\text { conseils }\end{array}$ & $\begin{array}{l}\text { avis } \\
\text { gouvernementaux }\end{array}$ & $\begin{array}{l}\text { Collaborate } \\
\text { Collabore }\end{array}$ \\
\hline
\end{tabular}

3 a) What are the factors that encourage communication between your municipality and other municipalities? Specialized organizations? Quels facteurs contribuent à encourager les communications entre votre municipalité et les autres municipalités? Organisations spécialisées?

\section{Municipalities Municipalités}

\section{Specialized organizations Organisations spécialisées}

b) What factors encourage collaboration between your municipality and other municipalities? Quels facteurs contribuent à encourager la collaboration entre votre municipalité et les autres municipalités? Organisations spécialisées?

\section{Municipalities Municipalités}

\section{Specialized organizations Organisations spécialisées}

4. a) What obstacles are there to communication between your municipality and other municipalities? Specialized organizaions? Quels obstacles à la communication pouvezvous identifier dans vos interactions avec les autres municipalités? Organisations spécialisées? 


\section{Municipalities Municipalités}

\section{Specialized organizations Organisations spécialisées}

b) What are the obstacles to collaboration between your municipality and others? Specialized organizations? Quels obstacles à la collaboration pouvez-vous identifier dans vos rapports avec les autres municipalités? Organisations spécialisées?

\section{Municipalities Municipalités}

\section{Specialized organizations Organisations spécialisées}

5. a) Has your municipality established any concrete goals concerning water quality management? (and the problem of blue-green algae?) Est-ce que votre municipalité a définit des objectifs concrets en ce qui concerne la qualité de l'eau, et plus précisément en ce qui concerne la qualité de l'eau (problématique des algues bleu-vert?) (plan d'urbanisme)

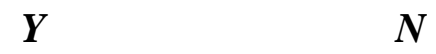

b) If the response is yes, on a scale of 1 to 5 how would you rate your achievement of these goals? 1 indicates not at all attained 5 indicates completely achieved. Si la réponse de 5a) est oui: Sur une échelle de 1 à 5, pourriez-vous évaluer dans comment ces objectifs ont été atteints?

1 signifie pas du tout atteint, 5 signifie complètement atteint.
Goal Objectif
1
Échelle Scale
$\begin{array}{lllll}1 & 2 & 3 & 4 & 5\end{array}$

6. a) On a scale of 1 to five how would you evaluate the importance your municipality gives to water quality (at the municipal level)? 1 indicates no importance 5 indicates lots of importance. Sur une échelle de 1 à 5, pouvez-vous évaluer l'importance que votre municipalité accorde à la qualité de l'eau? (au niveau municipal) Un signifie aucune importance, 5 signifie beaucoup d'importance.

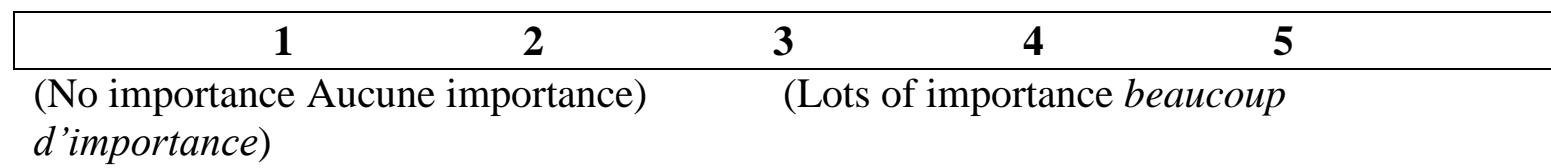

b) On a scale of 1 to 5 how would you evaluate the importance your municipality gives to the problem of blue-green algae (at the municipal level)? Sur une échelle de 1 à 5, pouvez-vous évaluer l'importance que votre municipalité accorde à la problématique 
des algues bleu-vert? (au niveau municipal) Un signifie aucune importance, 5 signifie beaucoup d'importance.

\begin{tabular}{|llllll|}
\hline 1 & 2 & 3 & 4 & 5 \\
\hline
\end{tabular}

(No importance Aucune importance) (Lots of importance beaucoup d'importance)

7. Again on a scale of 1 to 5 how would you evaluate the importance your municipality gives to the management of blue-green algae at a regional level? ToujoursSur une échelle de 1 à 5 , quelle importance votre municipalité accorde-t-elle à la question des algues bleu-vert au niveau régional?

\begin{tabular}{|lllll|}
\hline 1 & 2 & 3 & 4 & 5 \\
\hline
\end{tabular}

(No importance Aucune importance) (Lots of importance beaucoup d'importance)

Thank you very much for your participation! merci beaucoup pour votre engagement! 


\section{APPENDIX 2: WATER QUALITY MANAGEMENT ACTIVITES}

Activities undertaken by municipalities include required activities and activities undertaken under their own initiative.

\section{Required Activities}

Ability to reduce the amount of chemical products going on land

Collection of hazardous wastes

Design plans for septic pipes

Determine the distance of river buffer zone

Drinking water treatment facility

Enforce Government zoning regulations

Enforce rules for river buffer zone

Enforce rules on agricultural land

Identify and use designated sites for snow

Implicated in agricultural practices (e.g. tillage)

Implicated in changing the type of agriculture

Meet with other groups and talk about water quality management

Parks on the riverside

Protected areas around water by another actor group

Put septic instillations in place

Receive surface water sample results from the government

Take surface water samples

Talk about water quality at municipal meetings

Verify septic regulations are in place

Water treatment facility for municipality

\section{Initiative-based Activities}

Ecosystem inventories

Environmental management plan

Incentive program for agri-environmental practice.

Include water quality issues in local journal

Lake experiments

Municipal protected natural areas around water

Project for protection of riverside

River or lake clean up projects

Workshops at municipality on water quality management

Workshops with other organizations about water quality management 